\title{
From Settlements to Reparations: The Case of 'Comfort Women' and Jus Cogens in International Relations
}

\author{
Byoung Won Min
}

\begin{abstract}
This paper discusses the issue of "comfort women," which has been a hot topic between Japan and South Korea in terms of its implications for international relations in East Asia. The comfort women case needs to be dealt with as a test case for both countries' diplomatic capabilities and statecraft, as it has recently caused a grave stalemate in their bilateral relations and so has become a difficult issue for each country's political leaders. This paper argues that the issue of comfort women represents a new political dimension in the foreign policies of East Asia in the post-Cold War era. The issue is understood not so much as a diplomatic concern between two governments but as a broader political problem both at the regional and global levels. As such, the issue of comfort women needs to be unraveled using a shared, more compatible framework for a world community in which fundamental principles are overlapping. This paper tries to show how the case of comfort women has become a global political issue beyond the conventional framework of wartime punishment and postwar settlements.
\end{abstract}

Key Words: comfort women, jus cogens, settlements, reparations, East Asia

D iplomatic relations between Japan and South Korea have been deteriorating for the last several years due to tensions over the newly emerging issue of women forced by the Japanese Imperial government during World War II to work as prostitutes servicing Japanese soldiers, referred to as 'comfort women' because the brothels were known as "comfort stations." Whereas Japan and South Korea have sustained diplomatic linkages for half a century, relations between the two have been troubled by several tough issues such as territorial disputes, controversy over history textbooks, and apologies for Japan's colonial domination and wartime atrocities. The issue of the comfort women seems to have become a new signal for diplomatic confrontations between the two coun-

*Byoung Won Min (byomin@ewha.ac.kr) is a professor in the Department of Political Science and International Relations, Ewha Womans University. He received his Ph.D. in political science from the Ohio State University in Columbus, Ohio. His research has focused on theoretical aspects of international relations, with additional interests in the fields of security studies, cultural studies, and information technologies. This work was supported by the Ewha Global Top 5 Grant 2013 of Ewha Womans University.

The Korean J ournal of International Studies Vol.13-2 (August 2015), 441-460. http://dx.doi.org/10.14731/kjis.2015.08.13.2.441

(c) 2015 The Korean Association of International Studies 
tries since its resurgence as a new political and social concern among domestic groups, as well as bilateral relations in the early 1990s. Although the governments of both countries have treated the issue with serious concern, the situation seems to be worse now than during its early stages twenty years ago.

This paper discusses the case of comfort women, which has been a hot topic between Japan and South Korea in terms of its implications for international relations in East Asia. The comfort women case needs to be dealt with as a test case for both countries' diplomatic capability and statecraft, as it has recently caused a grave stalemate in their foreign relations and so become a hard mission for political leaders. Why has the comfort women case, unlike other disputes over diplomatic relations, caused so much persistent trouble even after more than seventy years and the normalization of formal relations? What are the problems in the attitudes and policies of both governments or populations in treating the claims and arguments over the comfort women? Can the people in both countries expect the matter to be resolved through diplomatic channels soon? In what ways should they attempt to change their approaches - both in Japan and South Korea - to resolving the issue if they want to overcome the current diplomatic gridlock?

This paper argues that the issue of comfort women has represented a new political aspect of foreign political relations in East Asia in the post-Cold War era. The issue, in this paper, is understood not so much as a diplomatic concern between two governmental agencies, but as a broader political one both at the regional and the global levels. This implies that the comfort women case may be hard to resolve using existing legal mechanisms or political compromises at the governmental level. It is less a bilateral problem for negotiations than a multilateral one that is serious enough to hold symbolic and public implications for the wider East Asian community, and perhaps the entire political world. As such, the issue of comfort women needs to be untangled using a shared, more compatible framework for the world community in which fundamental principles are overlapping. The paper, in this sense, tries to show how the case of comfort women has become a global issue for not only regional but also world politics beyond the conventional framework of wartime punishments and postwar settlements.

The arguments presented here for a new understanding of, and access to, the comfort women issue need not recall or describe the whole story again. This paper, on the other hand, tries to suggest an alternative framework, beyond the existing ones, for managing the issue among academic societies as well as policy experts and social and political groups in both countries. The next section, in an examination of the puzzles and motivations discussed above, explains what factors have made both countries fail since the 1990 os in their formal approach to the 
subject of comfort women. In succeeding sections, the need to replace the current mode of settlements with a new mode of reparations will be discussed. The trend for international norms to converge around more comprehensive and compatible global values, such as human rights, and the importance of such legal concepts as jus cogens, will also be discussed regarding their applicability to the comfort women case. The conclusions, with their implications for the international relations in East Asia, will follow in the final section.

\section{SETTLEMENTS: WHAT WENT WRONG WITH PREVIOUS APPROACHES?}

The emergence in the early 1990 s of a new quarrel over the Japanese Imperial government's WWII-era system of comfort stations was a legacy of structural aspects of the early Cold War. Although the two Koreas had escaped from Japanese colonial rule and had founded new modern states of their own, they could not escape concurrent misfortunes due to confrontations between the two superpowers - the United States and the Soviet Union - and their political influence in East Asia. Such structural factors as the Korean War and the decades-long Cold War had prevented both Koreas from accomplishing full-scale modernization and political autonomy like other newly emerging states in the post-WWII era. While Japan was quickly incorporated into the allied camp after the war, the legal status of South Korea was not the same as other countries in the postwar peace negotiation because of its colonial status. On the Korean Peninsula, this caused an incomplete resolution of the fallout from World War II and Japan's wartime behavior despite their formal terminations. During the negotiations for the San Francisco Peace Treaty of 1951, neither communist countries nor former Japanese colonial victims such as South Korea were invited. The treaty only partially settled the postwar relationship between Japan and the Allied Powers. No other multilateral conferences or bilateral treaties dealt directly with Japan's actions during the colonial era on the Korean Peninsula, not until the 1960s.

While many factors have contributed to this incomplete normalization of the East Asian political situation in the 1950s, the most important source must be found in the American 'policy of containment' in the region. The United States had intended to extend containment in Europe to the Asia-Pacific region, and so it quickly established a comprehensive framework of alliances to contain the expansion of communist revolutionary power and ideology in Asia. Containment culminated in the San Francisco peace treaty, whose terms were negotiated by the United States (Yahuda 1996, 113-114). Unlike in Europe, the United States had to 
wage two major containment wars in Asia at that time - in China and Koreawhich was enough to make American leaders and the public fear a communist threat in Asia. ${ }^{1}$ No comprehensive peace treaty for the whole of Asia was negotiated and signed, even though this might have alleviated the concerns of many regional powers such as communist China and the two Koreas. America rushed to conclude a security alliance with Japan in the early 1950s, which was extended later to other regional powers such as the Philippines, New Zealand, Australia, and South Korea (Schaller 1985, 293-294).

The legacy of America's containment policy heavily influenced the historical background of bilateral negotiations between Japan and South Korea in 1965 over normalization of diplomatic relations. As indispensable allies of the U.S. military strategy in East Asia, both countries were strongly encouraged to talk to each other and to conclude controversies over Japanese imperialist domination through compensation (Soh 1996, 1230). Their bargaining resulted in reopening diplomatic embassies and Japanese economic assistance to South Korea. The government of South Korea pledged that it would not claim any further recompense for the colonial period and its adverse effects. It seemed that the two countries had reached an agreement after two decades following World War II despite heavy domestic oppositions in both countries, especially in South Korea. Nobody had expected the issue regarding Japanese imperial rule to reemerge in the early 1990s, beyond more contemporary disputes over a small island, Dokdo/ Takeshima, and revisionist history in Japanese public school textbooks. The new conflict took a wholly different form - an unusual dispute over comfort stations, comfort women, and the Voluntary Labor Service Corps during the Pacific War. The surge of this new issue reflected the fact that the post-WWII peace system had never been completely resolved, neither through the San Francisco Treaty nor through the Japanese-South Korean normalization agreement in 1965.

One explanation for the incompleteness of the postwar peace system was that governments of South Korea and Japan tried to resolve the issue of redress for the colonial period of Japanese imperial rule - or the past injustices that resulted - only in terms of diplomatic settlements. The motivations of both countries were simple and yet very different from each other: the South Korean government

\footnotetext{
${ }^{1}$ The Cold War political system of Europe grew out of the Yalta Conference of 1945 between Great Britain, the United States and the Soviet Union, in which 'spheres of influence' in Europe were established. Scholars have interpreted the Cold War as either a 'state' or a 'structure': the former delineates the confrontations between the superpowers while the latter the structural dimensions of those confrontations. The 'state' of the Cold War was not a sufficient condition for the ending of it, though it was a necessary one, unless it was accompanied by the elimination of those Cold War 'structures' (Hara 2007, 2-3).
} 
wanted monetary compensation for economic development and the consequent legitimacy for the then-current military leadership, while Japan intended only to normalize its relations with South Korea as it had with other Southeast Asian countries that suffered under Japanese imperialism. The negotiation between representatives of both countries in 1965 was, despite different motivations, oriented toward the same result. The South Korean government and society experienced hard times in the domestic political arena because of this agreement because of the pledge not to claim collective or individual compensation from Japan for the damages and injustices during the colonial period. At least in terms of the agreement's legality, both governments officially had closed the issue of colonial compensation. In a strategic sense, the agreement helped both to achieve their policy goals - normalization of diplomatic relations and economic development. It was an important settlement in political as well as diplomatic terms.

After normalization of diplomatic relations between the two countries, South Korean society was relatively silent over the issue, even though there were protests and violent opposition right after the agreement. However, the contentious process of democratization in South Korea during the 1980s coupled with the sweeping trend of globalization in the 1990s have encouraged South Koreans to reflect upon their past and to refashion their identities away from authoritarian rule and the Cold War framework of that past. These changes led to social movements in many fields of Korea's civil society. The emergence of the comfort women issue was a part of that process. Personal testimony and academic studies on this issue were undertaken before it spilled over into the realms of politics and diplomacy in both South Korea and Japan. ${ }^{2}$ At the same time, the issue of the comfort women seemed to be more complex and harder to resolve than government officials expected. The intersectoral framework of the comfort women issue, which seeks to explain the dynamics within a multilevel framework of Japan's colonization of Korea - such as Imperial Japan's gender hierarchy and a 'patriarchal' ideology in Korea informing the social status of women - was only one among many different perspectives. These new approaches have yielded different interpretations of the historical issue among policymakers and academicians (Min 2003, 938-939). Also, while there has been copious amounts of testimony from witnesses for the comfort women case, the issue has been complicated by new demands for material evidence of forced sex slavery by Japan's wartime

\footnotetext{
${ }^{2}$ Professor Chong-ok Yun was the first Korean scholar to seriously investigate the topic of the comfort women in South Korea and led social movements at the national level in order to promote governmental and civil attention to the matter. She also served as co-chair of the Korean Council for the Women Drafted for Military Sexual Slavery.
} 
government. 3

However, despite comprehensive political changes in the post-Cold War era, the comfort women case had still been confined to conventional - both diplomatic and strategic - methodologies for resolution in both countries. Like the normalization treaty in 1965, both governments have attempted to resolve the matter through negotiations and diplomatic give-and-take. Patterns in the foreign policy of both the Park Geun-hye presidency in South Korea and the Shinzo Abe administration in Japan have not changed much from the approaches of past leaders, even though it is the $21^{\text {st }}$ century. This paper argues that the biggest problem creating gridlock between both countries is found in the deep crevasse between the complexity of the political situation surrounding the issue and the governmental sclerosis in dealing with it. In other words, neither the South Korean nor the Japanese government has adjusted to the new situation nor changed their policy orientations due to old-fashioned inertia. Both have tried to calculate the costs and benefits of programs of redress during negotiations, to communicate the matter to domestic audiences only in nationalistic terms, and to send unilateral messages to the other side and to global society. Because the approaches to policy of both countries have not matured, the issue has come to the current deadlock without any substantial breakthroughs. Japan and South Korea have struggled to find a compatible solution in the form of settlements, but it has been made clear that the issue has gone beyond current conventional frameworks for resolution.

The instances of civilian lawsuits show the invalidity of the settlement approach. One was filed by Korean comfort women to the Shimonoseki Branch of Japan's Yamaguchi District Court, which ordered the Japanese government to pay compensation to three South Korean comfort women (Kim and Kim 1998, 263-265). In 2003, after several rounds of legal disputes between the plaintiffs and the Japanese government, Japan's highest court decided that the defendant was to be exempted from responsibilities claimed by the plaintiffs. Another lawsuit was filed in the United States, where 15 women who were not U.S. citizens collectively sued the government of Japan claiming that two hundred thousand comfort women were forced to work as sex slaves during the war. This lawsuit requested that Japan not be immune from legal recourse under the U. S. Foreign Sovereignty Immunities Act (FSIA). The main argument of the plaintiffs was that the maintenance of 'comfort stations' by Japan was a violation of jus cogens, a

\footnotetext{
${ }^{3}$ More than 8,700 Japanese sued the Asahi Shimbun newspaper in January 2015 over its articles on the comfort women. The debate over the issue has moved from rhetoric over past wrongdoings to one of disagreement over historical facts.
} 
peremptory norm of human rights, and that the legal cover of sovereign immunity should not be permitted to Japan. However, the U.S. court did not support the plaintiffs' arguments, as the norm could not be applied to the core clause of the FSIA that was related to the condition of immunity; namely, commercial activity. 4

These two lawsuits are evidence that existing political and legal mechanisms are not sufficient to resolve the comfort women issue. Because the governments of South Korea, Japan and its court system, and even the government and court system of the United States, did not support the legal efforts of the comfort women, those institutions have experienced another backlash from domestic and transnational civil societies. Civic groups and individuals have gone to the streets after their defeats in the courts. These pushes have had a boomerang effect on both governments and on domestic politics generally. The rise of social movements around the comfort women issue in both countries has aroused tensions between both foreign policy doves and hawks and has elevated the voices of the latter to more extreme levels, though each has become more popular within their respective societies. The two governments may have no cards left to play because of the fierce divisions within those countries' civil societies. Conservative in both countries seems to be going head-to-head on the issue without offering any serious proposals that would be acceptable to the other side. That is why this paper argues that the current framework of diplomatic and political settlements may not be enough to resolve the comfort women issue.

The founding of the Asian Women's Fund by Japan was another case of policy failure with regard to the comfort women issue. The fund raised atonement money from Japanese society and many other non-state institutions, but it did not represent the official response of the Japanese government. Ironically, the fund was under government control, even though the Japanese government did not acknowledge any compensatory responsibility for the issue of the comfort women. This situation has revealed a big dilemma for Japan because of its incoherent posture between voices and acts, between causes and plans, and between official institutions and civil society (Soh 2003, 210). In 1993, Japan admitted that the military had been officially involved in the 'Comfort Station System,' and that those who had been victims of the system had been seduced by deceit or forced into the sexual labor, but the government still refused to accept legal responsibility for any wrongdoing. One of the main reasons for this irresponsibility, according to the Japanese government, was that war treaties and agree-

${ }^{4}$ See the descriptions on the case of Hwang Geum Joo v. Japan, 332 F.3d 679, 681 (D.C. Cir. 2003) in American Journal of International Law (2003), 686-688. 
ments prohibited liability and waived reparations (Lee 2003, 522). As such, the issue of the comfort women has been restricted from ordinary political discourse and legal mechanisms by the Japanese government. This has led to the rise of social movements and civic organizations in South Korea and elsewhere so that any political or legal solutions for both governments may not be available now. The mode of settlements seems to no longer be appropriate for resolving the critical issue of the comfort women.

\section{RISE OF THE NEW ISSUE OF REPARATIONS}

The process of politicization of the comfort women issue by social movements and civic groups, as discussed in the previous section, seems to have reduced the capacity of the Japanese and South Korean governments to achieve resolution (Soh 1996, 1232).5 It has reflected the emergence of new political dynamics, such as globalization, democratization, and the strengthening of human rights norms at the global level and their impact on domestic societies. How should the governments of Japan and South Korea respond to these new demands? How can they overcome decades-long domestic social and political hurdles in dealing with the new dimensions of this diplomatic issue? Regarding these questions, this paper proposes to replace the conventional state-centric perspective with one that is more appropriate to the changing nature of domestic, regional and global politics in the post-Cold War era in responding to the changing dynamics of the comfort women issue. The social, economic, and political situations that have developed since the 1990 s have transformed people's perceptions about historical injustices so much so that now they are incapable of being placated by oldfashioned approaches. This implies that we have to move from the policy of settlements to one of reparations, which will be explained later in this section.

The move towards reparations as a part of a redress for historical wrongs has been triggered by the U.S. Civil Liberties Act of 1988, which was intended to compensate both the victims of the 1923 Rosewood Massacre in Florida and the internment of Japanese Americans during World War II. The idea of reparation had been well known among American political activists working for racial justice in the 1960s, even though there have been, and continue to be, controversies over definitions and measurements. For example, many whites in America have not accepted the need for reparations to be paid to the descendants of former

\footnotetext{
5 The politicization of the comfort women movement in South Korea was also furthered by nongovernmental social groups, such as the Christian Women's Movement in the early 1990 .
} 
slaves, while most African Americans have supported it. The campaigns for reparations to atone for past injustices in America have become part of the culture wars, such as clashes over the secular role of religion, abortion, affirmative action, and racial discrimination. Since the development of these culture wars in America, the notion of reparations has become popular in other nations with its potential to be applied to many historical cases of injustices and transgressions against human rights (Brophy 2006, 3-7).

Programs of reparations are assumed to look both backward and forward at the same time. For measures of reparations to correct past injustices, they have to include truth commissions, apologies, and individual payments to compensate for well defined past harm. Reparations seek community-building projects in order to increase welfare of the entire society through funding for education, public works, and other recuperative programs. In this way, reparations seek corrective justice or distributive justice, which have their roots in the legal tradition of justice discourse. In this context, reparations are defined as: programs that are justified on the basis of past harm and that are also designed to assess and correct that harm and/or improve the lives of victims into the future (Ibid. 7-9). Reparations should focus on the past in order to account for the present so as to reveal the continuing effects of those past injustices. The notion of reparations, as such, assumes that past harm and injuries have not been adequately compensated for, so that the society should respond to this problem as a whole in order to identify and address the uncompensated harm (Ogletree 2003, 1055). The issue of past injustice, in this new discourse of reparations, has become part of the social agenda beyond the dyadic relationship between perpetrators and victims.

Also, reparations are distinguished from other methods of redress in that they target a large group of claimants on the basis of past wrongdoings that are difficult to alleviate under current law. As such, reparations are justified on the backward-looking grounds of corrective justice through such diverse forms as legal decisions, public policies, and government programs (Posner and Vermeule 2003, 691). Another point regarding the new understanding of reparations is that they should promote legislation for addressing group injustices that have been ignored by such political institutions as the court system. Scholars have insisted that reparations for group injustices committed in the past are possible beyond judicially imposed doctrines such as periods of prescription, sovereign immunity, and the denial of jurisdiction (Westley 1998, 434-435). Those legal mechanisms, whenever necessary, can be reconfigured to account for reparations through new legislation. ${ }^{6}$ The practice, which is called transitional justice, has

${ }^{6}$ This relates to Giorgio Agamben's idea of the state of exception as a paradigm for government 
been legitimized to bring a stable order and new sustainable norms to civil society under changing political circumstances. Such new norms would help disenfranchised groups seeking reparations beyond the conventional methods offered by litigation, which has served only to maintain the legacies of those old injustices.

In previous cases where legal systems have been used, 'reparation' has been narrowly interpreted as a response to past injustices in which perpetrators and victims were clearly distinguished from one another. On the other hand, in the legal understanding of this new notion of transitional justice, reparations are regarded as incorporating apologies and reconciliation measures in a broader sense. 7 The effort to come to terms with the past is the essence of reparations, while the term compensation implies only material or monetary solutions for past wrongdoings. While the notion of reparations has focused only on monetary compensation in its early usages for the survivors of the Holocaust in Europe, it has been expanded to hold broader connotations. In particular, reparation politics has been acknowledged as bringing greater weight to nonphysical harms and psychological trauma since passage of the Civil Liberties Act of 1988 that compensated Japanese Americans who were unjustly interned during WWII. As such, the concept of reparations has become popular as a standard way of referring to 'coming to terms with past injuries' (Torpey 2003, 3-4).

The trend toward using the broader term of reparations was the result of the combined effect of the development of human rights movements, the retrenchment of the Westphalian norm of sovereignty, and the elevation of individuals to higher status vis-à-vis nation-states in terms of international law. These are essential elements of post-Cold War politics and the integrative process of globalization that has enabled a paradigm change in international relations. In particular, the trend was possible because of two irreversible historical antecedents. First, it grew out of a flourishing discourse on universal human rights as a dominant global political norm. The Universal Declaration of Human Rights in 1948 and the emergence of NGOs such as Human Rights Watch and Amnesty International as institutional forces at the global level represented the claims for

by putting political factors ahead of legal mechanisms. Agamben, drawing on the political philosophy of Carl Schmitt, has suggested the new political situation, in the state of exception, allows the full powers of the government to gain legitimacy in initiating a new legal mechanism for political stability (Agamben 2005, 5-6).

${ }^{7}$ Scholars have agreed on a continuous relationship between a consolidated political system and a transitional period in their discussions of transitional justice. They are different from each other not in a categorical sense but in degree, so transitional justice is then seen as 'ordinary justice' (Posner and Vermeule 2004, 763-764). 
a universality and morality of human beings as being of intrinsic importance (Olick and Coughlin 2003, 39). Retroactive perspectives on past events, even those during WWII, have been reviewed and reclaimed for a new paradigm of reparations as part of human rights principles (Rubio-Marin 2006; Oette 2009). The same pattern, which reinterprets historical events in terms of human rights issues, was observed in the social movements for comfort women.

Secondly, the reparations discourse has been accompanied by the rise of 'transitology,' which originally was the study of the processes of political, economic, and social transformations following the democratization of authoritarian regimes in Latin America and the disintegration of the Communist bloc in the 1980s. The democratizing surge of the 'Third Wave,' as labeled by Samuel P. Huntington, urged people and governments to link the transition to revision and reassessment of their past (Huntington 1991). The past in those transitioning countries was regarded as the first project to be undertaken to secure a new and better, more equitable future. Those democratizing countries were assumed not to be able to go forward without clearing up past injustices. In the same context, the social and constructive implications of the comfort women issue do not pose a challenge to Japanese colonialism; instead, it is interpreted as an effort to overcome prejudices against women, which remain prevalent in modern Japan and South Korea. For example, protesters in these social movements have stressed the immoral practices of sex tourism by Japanese men in South Korea since the 1960 and criticized Korean historians and politicians who have been silent on the matter (Rodriguez 1997, 712). As a compound issue based on these multiple motivations, the case of comfort women has surfaced as a major issue for the women's movement in South Korea.

Beyond these two aspects, the politics of regret and reparations may be explained as a part of historical-sociological transformations due to the demise of nation-states. This was considered peculiar in the early 1990 os when the Cold War system began to collapse. The frequent outbreaks of financial crises, terrorist attacks, and extreme gaps in income distribution have proven the impotence of nation-states, which have relied on fulfilling those functions to bolster their legitimacy. State authorities began to be context-dependent upon shared value systems, what the philosopher Hannah Arendt referred to as the zeitgeist (Arendt 1969,98 ). Alternative searches for replacing incompetent states, such as counterhegemonic movements, have become ordinary political phenomena internationally as well as domestically. ${ }^{8}$ As we had become familiar with the notion of states

${ }^{8}$ The law, in this context, is not separated from political motivations and competitions but just encourages a form of political action (Shklar 1964, 143). This implies that we may have to search for 
only as the anti-thesis of the economy over the long run, the emergence of these voluntary associations among social and transnational civil societies has been a novel experience for many individuals. The prevalence of social movements everywhere represents the emergence of a 'postmodern prince' who constructs new social institutions in order to adapt to new political situations. Contemporary transnational civil society, in the form of a collective will, began to assert itself in practical terms to realize its ambition to build alternative transnational institutional frameworks alongside conventional nation-states (Gill 2000, 137-138).

The trend toward social and constructive reparations beyond traditional settlements has been reflected in the political environments and transformations in the post-Cold War era. Reparations for past wrongdoings do not need to be restricted to compensating victims or offsetting their losses, but they symbolize the integrity of a society that would not forget past histories and injustices. In contrast to the past conventions in resolving postwar problems developed during the San Francisco Treaty system in the early 1950 and the next phase of localization and increasing tensions thereafter, the new trend of social reparations in the 1990 s has revived the notion of transitional justice as a global norm for each society to adopt as an institutional mechanism for their transitioning periods. ${ }^{9}$ As such, societies are to keep their sustainability and integrity in this changing environment. These changes would increase a dignified sense of identity-in-memory for the people in that society (Waldron 1992, 6-7). In this way, treating the issue of past injustices from a community perspective has raised public recognition that historically those publics had experienced injustice and have tried to correct for those injustices by making related issues socially (or globally) relevant and shared by the whole community. The symbolic dimensions of reparations, as such, are so important in keeping a domestic or global society sustainable and adaptable to changing environments.

The emergence of comfort women as a social issue, in this sense, is to be understood in the same framework of transitional justice and social movements that have challenged the authority and legitimacy of modern states. ${ }^{10}$ The issue seems

political alternatives to restrictive legal approaches in dealing with difficult social and historical problems, such as in the case of the comfort women.

${ }^{9}$ The issue of transitional justice has experienced three historical phases. The first started with the postwar systems of reparations, such as the Nuremberg and Tokyo war crimes trials, which were focused only on ending the war and punishing perpetrators. A general equilibrium was the final result of this phase when an impasse was reached. The second phase was associated with the global trend of democratization and the subsequent political struggles that had pushed newly emerging democracies to establish new norms of transitional justice. The third phase in the post-Cold War era featured the acceleration and diffusion of the norm of transitional justice with the accompanying trend of globalization (Teitel 2003, 70-72). 
to have gone beyond the level of the nation-state to be extended to the global level. This implies that we have to overcome the limits imposed by conventional foreign policies and strategies at the national level or at the regional level in order to reach the global level. The more countries and regions that have embraced globally governing cultural, moral, institutional, and material resources, the greater the possibility for support for transitional justice to be accepted as a global norm. Countries around the world have expanded to embrace more compatible principles in a social way, which has eventually led to the development of those principles in a more institutionalized form. ${ }^{11}$ That is why the comfort women case has drawn so much attention from countries and world society. We then may have to recast the issue in light of a global standard of social construction, particularly in terms of the doctrine of jus cogens.

\section{THE DOCTRINE OF JUS COGENS AND THE COMFORT WOMEN CASE}

Assuming shared global standards of reconciliation and justice involves defining a right relationship among diverse political communities. Members of these communities expect upholding the right from their members and from other groups and communities. International law has played a role in the process of standardization, even though it has functioned less as a constitutional norm in world politics than as an evolving institutional principle during the last few centuries. For example, an increasing number of standards of justice-for example, human rights laws, jus ad bellum and jus in bello, and anti-terrorism principles - have been established among members of international society through the codification of international laws. Countries have socially constructed human rights norms and institutions, such as the International Covenant on Civil and Political Rights (ICCPR) and the International Covenant on Economic, Social and Cultural Rights (ICESCR), only recently during the $\mathbf{2 0}^{\text {th }}$ century (Henderson 2010, 292-

${ }^{10}$ The United Nations has endorsed the approach of transitional justice as an alternative way for resolving past injustices. The UN's suggestions for employing this new approach of transitional justice include developing meta-norms that could apply to local contexts, creating political institutions involving all stakeholders and seeking a consensus among them, and approaching transitional justice in a comprehensive and holistic manner (United Nations Security Council 2004).

${ }^{11}$ For example, international society has developed the principle of humanitarian intervention as a global norm. Any widespread violations of human rights are now considered an acceptable reason for international society to intervene, including militarily, to change a country's domestic and foreign policies (Engle 2007, 190-191). 
300). These institutions, as evolving mechanisms for advanced international transactions, have constructed a reliable set of principles of justice to be compatible with the beliefs and values of different groups and societies.

Global justice standards as compatible norms of behavior, however, have been accepted primarily by the countries heavily influenced by Western civilization. Based upon the shared traditions of Hellenism and Christianity, the West has reached an overlapping consensus on a set of common principles and norms, such as the rule of law, democracy, and universal human rights. Although these elements have never been complete employed, they have constructed a sort of code of honor to guide and control the behavior of community members. In this way, standards have become universal in the West and eventually have been exported to the rest of the world through European colonialism in the late $19^{\text {th }}$ century and American hegemony today (Philpott 2012, 20-21). East Asia was only one of those colonized regions that was underdeveloped compared to, and much exploited by, the West. Except for Japan, most East Asian countries have been so eager to transition out of their past colonial situations and accelerate their modernization plans during the Cold War period. The domestic policies that resulted from this desire to move away from the colonial past have led many East Asian countries to ignore those behavioral and ethical standards both at the regional and global levels. Globalization, accompanied by democratization and the rise of civil society, was a turning point for these states to take another step towards introducing those global standards to domestic society.

The status of comfort women, in this new post-Cold War political situation in the 1990s, was no longer considered a viable issue in bilateral diplomatic relations among East Asian states. Instead, it became a symbol of the victims of human rights violations. Norms related to human rights or women's rights were beginning to be incorporated as a fundamental source - the so-called jus cogens - of international laws and institutions. The doctrine of jus cogens is now an accepted principle in international law and norms with which treaties must not come in conflict. While the conventional practice of modern international relations has acknowledged states' sovereign power to conclude treaties, and while those sovereign states are in principle empowered to negotiate international agreements on any subject, some norms of general international law can no longer be repealed by those treating-negotiating states. This means that now there are some peremptory norms of international law that are jus cogens, and from which no derogation is permitted by agreement. The trend for more jus cogens legal norms to emerge in contemporary international relations heralds the relative decline of the dominant positivist doctrine informing past international law (Verdross 1966, 55). ${ }^{12}$ The doctrine of jus cogens has embraced humanitari- 
an principles and war-related norms that were declared in the Charter of the United Nations and in other international treaties. Jus cogens, as such, has been an effective tool to allow states to accept and achieve profound changes in existing norms that would restrict state behavior.

The doctrine of jus cogens has informed a body of higher law for the international community since the concept's introduction during the Vienna Convention of 1969 and its confirmation in the Vienna Convention of 1986 on the Law of Treaties. As the world community has become increasingly interdependent, that community has needed a more sophisticated public order for the stability and sustainability of global society. Nevertheless, the nature of international anarchy has prevented any completely effective and legitimate legislation for the whole global community beyond what is enforceable under the current system of state sovereignty. The introduction of jus cogens can be interpreted as a compromise between the need for global public order and justice and the conventional system of state sovereignty. While the doctrine of jus cogens lacks legislative power and genuine consensus among all members of the community, it has emerged as an ad hoc agreement for how to manage global matters during humanity's march toward a world republic (Danilenko 1991, 64-65). Like the issue of genocide in the 1990s, the case of the comfort women has become a focal point in the trend toward more reliance on the doctrine of jus cogens at the global level to address the past. This implies that international society should and will resolve the case as a violation of jus cogens similar to the logic informing humanitarian interventions in conflict-ridden regions. Although no significant measures have yet been concluded by the United Nations, the issue of the comfort women seems to have garnered - and will continue to garner - more attention from world society as a benchmark for the application of the doctrine of jus cogens. ${ }^{13}$

Since the 1990s, international society has accelerated its transformation from its sovereignty-centered Westphalian nation-state system to a new paradigm of international interactions more weighted towards universal and individual human rights. Although the principle of human rights - as an element of jus cogens - has yet to replace the supremacy of the principle of sovereignty, it seems to have caused a significant retrenchment of the state. This is based on the com-

\footnotetext{
${ }^{12}$ Many international norms, such as the prohibition of genocide, piracy, slavery, torture, and wars of territorial expansion, have been established during the last century as 'peremptory,' or jus cogens, which are legal norms that cannot be altered even through state agreements (Henderson 2010, 220).

${ }^{13}$ These days, crimes against women during armed conflict are not limited to sexual violence, and so they must be resolved through truth commissions rather than solely through the prosecution of perpetrators (Turano 2011, 1046).
} 
mon recognition among members of the global village that state sovereignty has been, in many cases, a barrier to international governance. This logic also has been applied to the foundations of international law. Nowadays, the consent of states is not the only source of legitimacy of international law. Many sources for these norms have, whenever necessary, emerged in order to help resolve issues that cannot be resolved by states operating in a modern international system. As such, international legal principles regarding human rights have penetrated nation-states and addressed the condition of human rights within those states. Regardless of the domestic political situation of states, human rights norms have become the jus cogens on which states have not consented (Henkin 1995/96, 3233). The changing nature of international relations has transformed international law in terms of its sources of legitimacy and its enforcement mechanisms. Nation-states are only a single actor operating within a global system of international legal principles and mechanism as the doctrine of jus cogens has evolved to meet the challenges of international governance. ${ }^{14}$

During the last half century, international law has developed and expanded to incorporated concepts and mechanisms related to terms of reparations. First of all, the focus of international law has shifted from the protection of citizens and their property to the protection of individuals under the threat of human rights abuses. Also, states have been recognized as responsible for those violations of human rights, and those victims increasingly have sought relief and compensation. Eventually international law has become less concerned with the identification of victims and the sovereign immunity of the state than with the availability of legal relief for those victims. More measures have become obtainable at the regional or the global level whenever nation-states cannot provide enough protection or redress for victims. In this way, international law, as a dynamic mechanism for changing political environments and global governance, has shifted from dispute settlements to the more appropriate reparations for human rights violations (Falk 2006, 485). The overall trend, as such, has emphasized the protection of human rights to take precedence over the sovereignty of the nationstate. These changes in international law and the development of jus cogens have enabled the case of the comfort women in Korea and elsewhere to become a global issue of reparations for human rights violations as an element of jus cogens beyond the traditional purview of state-regulated foreign policy.

\footnotetext{
${ }^{14}$ Also, there has been noticeable progress in establishing compliance or enforcement mechanisms of international law. International law, through horizontal enforcement mechanisms capable of making states honor their obligations by the coordinated efforts of a diverse set of political actors, has been held up as a model for global governance.
} 


\section{CONCLUDING REMARKS: IMPLICATIONS FOR EAST ASIA}

How can we respond to the claims over the past when there are no agreed upon standards to be applied to those claims? Many cases, such as the Holocaust, Gulag Archipelago, World War II atrocities, and discrimination within states, could be used as good examples as guides to resolving the case of the comfort women, but we have to know that each case holds both particular and universal dimensions at the same time. So, we may not regard only one case as a benchmark for all other cases. However, global political norms have been converging towards a system of standards that are compatible among more people and across diverse regions. Norms about human rights is only one example of these convergences, even though the traditional legacies of nation-states may last longer than we expect. The discourse on 'coming to terms with the past' may need renovations in consideration of these political changes at the global level. The comfort women issue, in this context, can be a multilateral subject that signals the current state of our norms on global human rights. That is why this paper argues for a change in thinking about the issue from the conventional method of resolution of state settlements to one of reparations.

The expression 'coming to terms with the past' implies reviewing the behavior of our predecessors and our own behavior in terms of the consequences for current and future generations. It is composed of many elements, such as prosecuting those responsible, punishing guilty persons, apologizing to the victims, paying compensation, providing symbolic recognition, and others. These steps are necessary whenever the perpetrators, victims, and their successors coexist in the same community. The process of reconciliation between those who would cohabitate is a necessary step for the future beyond resolution of past injustices and their legacies (Cairns 2003, 66). Then the possibility of achieving true reparations for those past injustices and of establishing more conciliatory measures throughout international society will grow. Unlike many previous diplomatic settlements, the case of the comfort women should be resolved based on the global principle of individual human rights, which is a part of jus cogens, instead of the traditional principle of state sovereignty.

Politics, whether domestic or international, need not always be based solely on rational calculations, in the sense that we have to consider only the costs, benefits and maximum utilities. The historical period for those strategic calculations has passed with the end of the Cold War. A new approach emphasizing our shared commons, one that is accepted among diverse members of our global community, is required and available. This is the right time for Japan and South Korea to change their approaches based on the old narrow strategic logic to one that is new, 
broad, emotional and moral. This means that we need true reparations instead of formal settlements. That is the only way for both countries to settle their problems in a manner that is compatible with global standards on human rights. Global norms regarding transitional justice have expanded to every corner of world such that any regional resolution of the comfort women question must reflect those norms. Otherwise, both countries will face more violent social perturbations domestically, as well as global pressures for more jus cogens for human rights. This is why the case of the comfort women should be treated differently from other resolutions of diplomatic disputes, and why true resolution of this issue of the past ought to be the touchstone for future international relations in East Asia.

\section{REFERENCES}

Agamben, Giorgio. 2005. State of Exception. Chicago: The University of Chicago Press.

Arendt, Hannah. 1969. Crises of the Republic. San Diego: A Harvest Book.

Brophy, Alfred L. 2006. Reparations Pro \& Con. Oxford: Oxford University Press. Cairns, Alan. 2003. "Coming to Terms with the Past." In John Torpey ed., Politics and the Past: On Repairing Historical Injustices, Lanham: Rowman \& Littlefield Publishers, 63-90.

Danilenko, Gennady M. 1991. "International Jus Cogens: Issues of Law-Making.” European Journal of International Law 42, 64-65.

Engle, Karen. 2007. "'Calling in the Troops': The Uneasy Relationship among Women's Rights, Human Rights, and Humanitarian Intervention." Harvard Human Rights Journal 20, 189-226.

Falk, Richard. 2006. "Reparations, International Law, and Global Justice: A New Frontier." In Pablo de Greiff ed., The Handbook of Reparations. Oxford: Oxford University Press, 478-503.

Gill, Stephen. 2000. "Toward a Postmodern Prince? The Battle in Seattle as a Moment in the New Politics of Globalization." Millennium 29(1), 131-140.

Hara, Kimie. 2007. Cold War Frontiers in the Asia-Pacific: Divided Territories in the San Francisco System. London: Routledge.

Henderson, Conway W. 2010. Understanding International Law. West Sussex: Wiley-Blackwell.

Henkin, Louis. 1995/96. "Human Rights and State 'Sovereignty'." Georgia Journal of International and Comparative Law 25, 32-33.

Huntington, Samuel. 1991. The Third Wave: Democratization in the Late 
Twentieth Century. Norman: The University of Oklahoma Press.

Kim, Chin and Stanley S. Kim. 1998. "Delayed Justice: The Case of the Japanese Imperial Military Sex Slaves." Pacific Basic Law Review 16(2), 263-280.

Lee, Sue R. 2003. "Comforting the Comfort Women: Who Can Make Japan Pay?" University of Pennsylvania Journal of International Economic Law 24(2), 509-547.

Min, Pyong Gap. 2003. "Korean 'Comfort Women': The Intersection of Colonial Power, Gender, and Class." Gender and Society 17(6), 938-957.

Ogletree, Charles J. 2003. "The Current Reparations Debate." U. C. Davis Law Review 36(5), 1051-1072.

Olick, Jeffrey K. and Brenda Coughlin. 2003. "The Politics of Regret: Analytical Frames.” In John Torpey ed., Politics and the Past: On Repairing Historical Injustices. Lanham: Rowman \& Littlefield Publishers, 37-62.

Oette, Lutz. 2009. "Bringing Justice to Victims? Responses of Regional and International Human Rights Courts and Treaty Bodies to Mass Violations." In Carla Ferstman, Mariana Goetz and Alan Stephens eds., Reparations for Victims of Genocide, War Crimes and Crimes against Humanity: Systems in Place and Systems in the Making. Leiden: Martinus Njihoff, 217-242.

Philpott, Daniel. 2010. Just and Unjust Peace: An Ethics of Political Reconciliation. Oxford: Oxford University Press.

Posner, Eric A. and Adrian Vermeule. 2003. "Reparations for Slavery and Other Historical Injustices." Columbia Law Review 103, 689-747. . 2004. "Transitional Justice as Ordinary Justice." Harvard Law Review 117(3), 761-825.

Rodriguez, Junius P. ed., 1997. The Historical Encyclopedia of World Slavery. Santa Barbara: ABC-Clio.

Rubio-Marin, Ruth. 2006. "The Gender of Reparations: Setting the Agenda." In Ruth Rubio-Marin ed., What Happened to the Women? Gender and Reparations for Human Rights Violations. New York: Social Science Research Council, 20-47.

Schaller, Michael. 1985. The American Occupation of Japan: The Origins of the Cold War in Asia. Oxford: Oxford University Press.

Shklar, Judith N. 1964. Legalism: An Essay on Law, Morals and Politics. Cambridge: Harvard University Press.

Soh, Chunghee Sarah. 1996. "The Korean 'Comfort Women'.” Asian Survey 36 (12), 1226-1240.

. 2003. "Japan's National/Asian Women's Fund for 'Comfort Women'." Pacific Affairs 76(2), 209-233. 
Teitel, Ruti G. 2003. “Transitional Justice Genealogy.” Harvard Human Rights Journal 16, 69-94.

Torpey, John. 2003. "Introduction: Politics and the Past." In John Torpey ed., Politics and the Past: On Repairing Historical Injustices. Lanham: Rowman \& Littlefield Publishers, 1-34.

Turano, Laura C. 2011. "The Gender Dimension of Transitional Justice Mechanisms." International Law and Politics 43, 1045-1086.

United Nations Security Council. 2004. "The Rule of Law and Transitional Justice in Conflict and Post-Conflict Societies." Report of the SecretaryGeneral. S/2004/616.

Verdross, Alfred. 1966. "Jus Dispositivum and Jus Cogens in International Law." American Journal of International Law 60, 55-63.

Yahuda, Michael. 1996. The International Politics of the Asia-Pacific, 1945-1995. London: Routledge.

Waldron, Jeremy. 1992. “Superseding Historic Injustice.” Ethics 103, 4-28.

Westley, Rober. 1998. "Many Billions Gone: Is It Time to Reconsider the Case for Black Reparations?” Boston College Third World Law Journal 19(1), 429-476.

[Received J une 1, 2015; Revised August 13, 2015; Accepted August 18, 2015] 